\title{
DEVELOPMENT OF THE TRADITIONAL DIGITAL GAMES FOR STRENGTHENING CHILDHOOD'S VERBAL SKILL
}

\author{
Nuur Wachid Abdul Majid \\ Universitas Pendidikan Indonesia \\ Taufik Ridwan \\ Universitas Pendidikan Indonesia
}

\begin{abstract}
The aims of this research was to: (1) know the portability aspect of the Traditional Digital Games application as a medium for early childhood learning; and (2) know the usability aspect of the Traditional Digital Games applications as a medium for early childhood learning. The method used in this study is Research and Development $(R \& D)$. The stages through which the waterfall will be useful to be able to produce reliable and effective software. The waterfall flowchart consists of: analysis, design, implementation, testing, and improvement. The results of this study were: (1) the results of testing from the portability aspect using a different smartphone, it can be concluded that traditional digital game applications have entered into a very good category; and (2) the results of testing usability aspects averaged over $70 \%$, so that in both aspects the test was considered feasible and good. Although in the aspect of learning games the score shows $70.83 \%$ so it needs an increase. Keywords: traditional digital games for learning, education, verbal
\end{abstract}

Permalink: $h t t p: / / d x . d o i . o r g / 10.21831 / j p v . v 9 i 1.22802$

Contact Nuur Wachid Abdul Majid nuurwachid@upi.edu

Universitas Pendidikan Indonesia, Jl. DR. Setiabudhi No.229, Isola, Sukasari, Kota Bandung, Jawa Barat 40154, Indonesia 


\section{INTRODUCTION}

Information and communication technology (ICT) has rapidly developed that all fields are using ICT to improve their activity. It has a positive and negative impact on several aspects. One of negative impact that using technology is children's growing motoric skills. Children will tend to be lazy to learn, if they know of game online (Pribadi, 2010). Children were getting violent content in a game without parental monitoring. They were threatened with negative information on the internet. The negative impact that found on the internet must be systematically prevented. Although, psychologically children prefer to use media gadgets as a tool to play.

Now, the traditional games have been forgotten by children since the digital games are easily obtained through gadgets. Firdaus (2017) said that $65 \%$ of children in Indonesia were not known of traditional games as the impact for development of technology. This situation was a threat to all, because technological devel-opments are increasingly massive and the role of parents to children is very lacking in educating and supervising their activities. Recognition of traditional games takes a long time and does not provide gadgets to children up to adulthood. Although in essence the role of gadgets in the current era is very high so that children are more preoccupied with electronic devices than traditional games.

The use of gadget for children has increased with the massive circulation of gadgets. Besides, parents' tendency to give gadgets to children who were hoped communication and learn with gadgets that have been impacting of increasing gadgets users. According the new research found that at least 30 million children and teenagers in Indonesia were the internet users and digital media (Sembiring, 2014).

Using education applications on gadgets can improve children's ability to see, hear and speak. The results of research by Joan Ganz Cooney Centre that five-year-old of children who use education application on Ipad have increased of vocabulary at least $27 \%$, while three-year-old of children have increased of vocabulary at least $17 \%$ (Wulandari, 2016). So, the gadget has a good impact on children if given a good application.
Digital game has interested by children, so the developer of digital application has innovated for designing and creating a game that has interested by children. One of designer and game advertising, Agate Studio, Dave Febrian shared his idea for developing the traditional game that it can be played comfortably and excitingly on a smartphone (Febrian, 2015). Febrian tried to bring his core experience when he saw children playing Sobyong (the game called Pancasila 5 Dasar in the Yogyakarta area) skillfully, even though today's children are usually more interested in playing video games. So, Agate Studio launched the application of Kuis Pancasila 5 Dasar with the aims of introduction traditional game for children. They will be increasing insight of nationalism related to the types of traditional games in Indonesia that the traditional game is more interesting than modern games. Children will add visual intelligence through typical of national displays packed with the latest designs.

Saputra \& Ekawati (2017) did research on improving basic skills for children through the traditional game. The result of this research was to 13 traditional games have a good impacted to improve children' competencies. Competencies that were increased after played traditional games were kinesthetic, linguistic, logical-mathematical, visual-spatial, musical, natural, interpersonal, intrapersonal, and spiritual intelligence.

Traditional digital games are the media for learning that improves vocabulary and insight nationalism for childhood. It can be an alternative choice for educating and improve language skills for childhood. Traditional digital games are expected to popularize traditional Indonesian games to the global market. Thus it is necessary to design and develop Traditional Digital Games that they can be used as learning media for early childhood.

Electronic based games can provide motivation to learners. Enhance the use of education that is based on electronic games due to its importance in motivating learners (Alanazi, 2017). Teachers are aware that their roles when using new technologies in education have changed, specific curricula, pedagogy and practice highlights the need for a flexible model or approach of embedding digital games into primary classrooms (Allsop \& Jessel, 2015). The teachers were very concerned about the application of technology and the rules if 
applied to children. Pedagogical curricula and practices also require a flexible model for the application of digital games in the elementary school class.

Mobile game is a game that can be run on a mobile phone or cellular, so that users can play portable. Mobile games can be grouped into three categories: the first embedded game, which is a game that is embedded in a mobile device system (Shiratuddin \& Zaibon, 2010). The second is a frequent SMS game in the form of live contest and polling. The types of mobile games can be classified as follows: Arcade /Action for example Doom and Alien; Sports for example bowling, golf, and football; Skills, strategies, and logic, for example Sudoku; Cartoons and boards, like monopolies; Game playing for example is final.

The implementation of education in Indonesia aims to ensure that the competencies taught by teachers can be accepted by students, and can master them thoroughly. Mastery of competence for students is a very important thing, because it can be a provision later when students face the dynamics of life. The process of mastering this competency sometimes has problems, because students do not understand the things given by the teacher.

Students' success in mastering competence is caused by many factors, one of which is employability skills. Employability skills require many skills that are ready in a career, work skills, technical expertise and academic knowledge (Majid \& Sudira, 2017). This capability requires a relatively long time and is not instant. Students must go through many processes to obtain these abilities.

The impact of traditional games can improve various mental aspects in the players. As the results of research conducted by Dehkordi (2017) related to traditional games, that there is an influence on mental development through traditional games. Impacts on mental development with traditional game: (1) improving mental and spiritual strength and capabilities; (2) balancing emotions and managing and controlling; (3) eliminating conditions; (4) Creating balance in competition and openness to reasonable rules; and (5) achieving vivacity and high-spiritedness as important elements in continuous development (Dehkordi, 2017).

Oray-Orayan is a digital game that will be developed by adopting the traditional dragon snake game, while Luluncatan adopts jump rope. The second concept of the game is to provide learning to early childhood to stay familiar with traditional treasures of the archipelago. This can stimulate children to try and apply it to the real world. Thus the preservation of the culture of the archipelago will grow in children and the cultivation of national character values can work well. The traditional media-based digital games can be an alternative to support the learning done by the teacher. Students can play cheerfully and smartly with teacher supervision. This is also supported by the results of the Vitianingsih (2016) studied that examines related educational games that can help learning. This educational game can help PAUD teachers and students to change conventional learning methods into simulation learning ways with game media and make it easy for PAUD students to learn about symbols, counting, matching images and composing random words.

The aims of this research was to: (1) know the portability aspect of the Traditional Digital Games application as a medium for early childhood learning; and (2) know the usability aspect of the Traditional Digital Games applications as a medium for early childhood learning.

\section{METHOD}

The method used in this study is Research and Development ( $\&$ D). This research was intended to combine fun learning with technological development. The output of the research will produce a game product prototype for the process of strengthening children's verbal abilities in recognizing letters and reading and improving children's visual-spatial intelligence.

In the steps taken in making the game using this R \& D method, a software design was used the waterfall method. The stages through which the waterfall will be useful to be able to produce reliable and effective software. This method is a method in soft design that starts from the analysis phase until the software can be operated (Pressman, 2010). The process of making software that is passed is the phase of needs analysis, compounding, programming (coding), testing, to the operation of the software. 


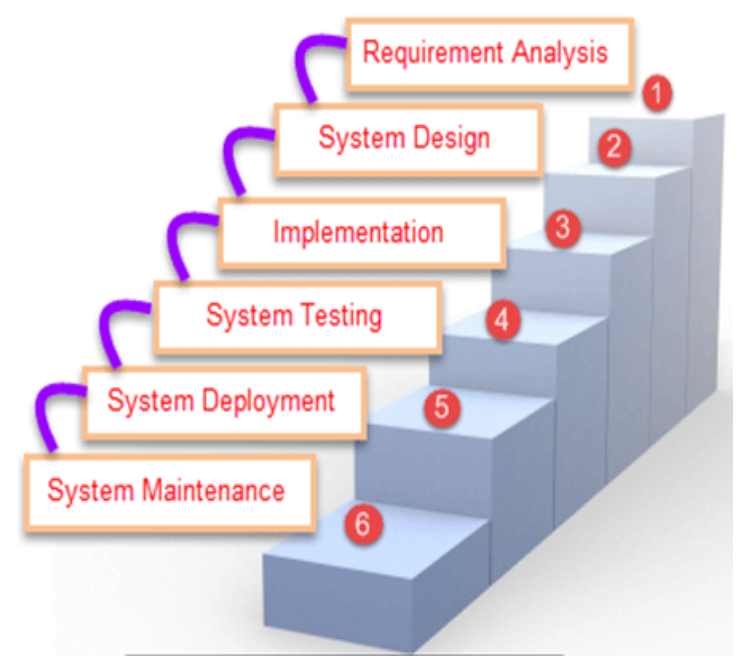

Figure 1. The waterfall flow chart in software development

The trial subjects in this study were intended for testing aspects of functionality and usability. Research subjects on functionality aspect were people who are experts in the field of software engineering. While the usability aspect is students or early childhood in aera Purwakarta.

The game development process will be carried out at 7 months of research. The game is designed to have two main screens namely the initial interface of the game, and the interface to the core game.

\section{RESULTS AND DISCUSSIONS}

\section{Results}

The game is one medium that is quite fun for the learning process, but the reality is just the opposite. Today's gaming market is filled with games that have a lot of content that presents elements of violence as its main element. This can cause a negative influence on child development.

Gadgets users also spread to children, making gadgets the main part of daily activities. Children are more fun playing with gadgets than with peers or playing outside the home. This condition makes children prefer to stay at home rather than going out with their friends. This phenomenon results in children being far more introverted and not good for children's psychological development (Yas$\min , 2016$ ).

One effort that can be done is to transform traditional games into digital forms.
To be able to make games that can improve verbal abilities and visual-spatial intelligence of children, it is necessary to do several processes so that the resulting games can be beneficial for children. The main target of game board design is children aged 3-10 years who are still in kindergarten or elementary school. However, it does not rule out the possibility of this game being played by all circles. The main requirement is feeling curious, wanting to learn, and trying new things.

The analysis phase started by recording everything needed by the game to be designed. Games that will be designed are luluncatan and oorayan. This name was taken to attract the attention of the child and cause curiosity of the child to find out the meaning of the word in the local language.

System modeling analysis is how to describe the data flow model and functional system when running. The modeling used in this study is the Unified Modeling Language.

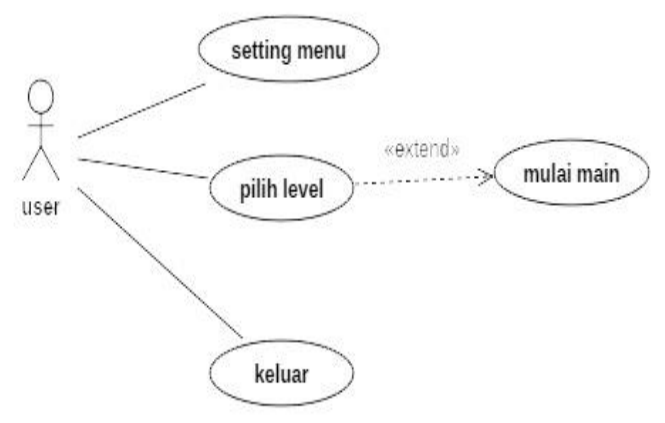

Figure 2. Use Case Diagram Analysis

From the figure, it can be explained that the system has 3 activity pieces or something that can be done, namely menu settings, select levels, and exit. When a user selects a level, it will automatically be taken to another activity, which is starting to play.

When a user plays a game, the user must still jump to the right and left of the screen not to be hit by the obstacles in front of him. On top of the game screen, there are certain words. Players must capture the letters according to the words at the bottom of the screen. Children who play this game will be tested for their understanding of verbal ability to recognize letters and visual-spatial intelligence on letters that are rotated in corners. 
The storyboard was created to find out the content design for each part of traditional digital games to describe the series that were carried out at each stage through the game. Making storyboards is expected to facilitate the flow of games to be developed.

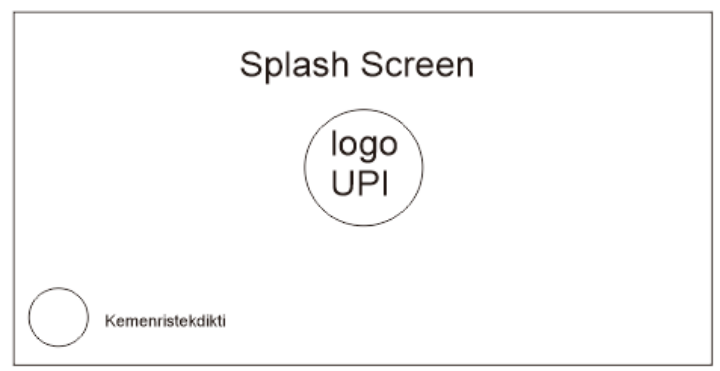

Figure 3. Display of Splash Screen

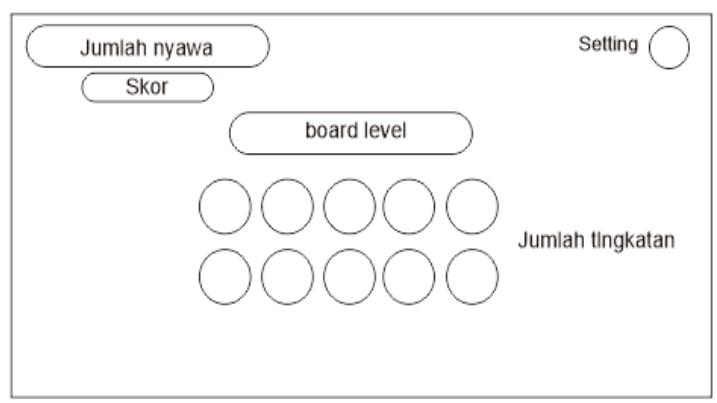

Figure 4. Display of the Game Each Levels

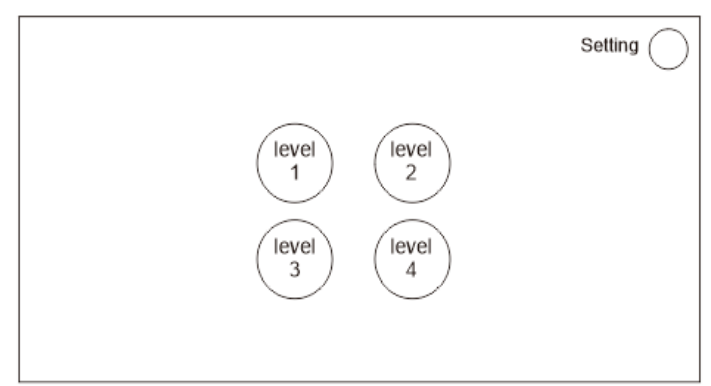

Figure 5. Display of the Game Level Options

Product manufacturing is done after all stages in planning and design have been completed without any revisions. Product manufacturing is based on the requirements stated in the collection of materials so that the product can be produced properly. At this stage, the realization of the design has been carried out so that the appearance of the product is similar to what was designed.

The next development is coding the application that it can run well. It was using the Unity application. Unity is an integrated tool for creating games, building architecture and simulation. Unity 3D was first released only on
Mac Platform, the OS from Apple products. Over time, Unity 3D can be run on other operating systems, such as Windows and Linux. Basically, Unity is a 3D based game engine.

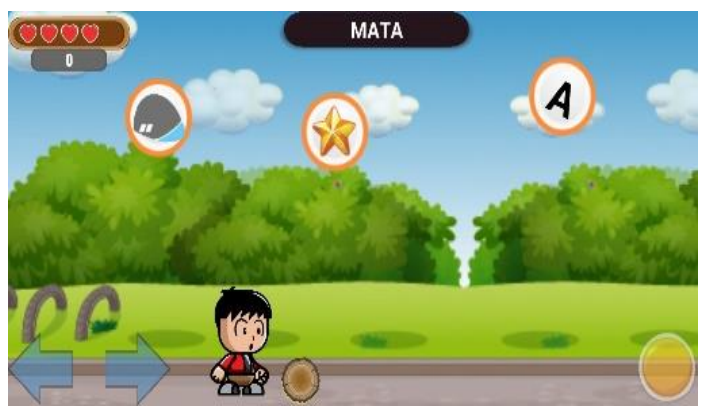

Figure 6. Display of the Game Luluncatan

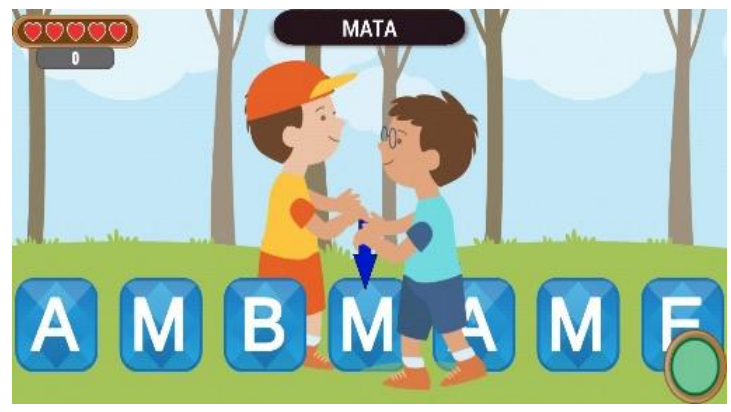

Figure 7. Display of the Game Oorayan

This coding can be combined with designs that have been designed with the code entered into the unity application.

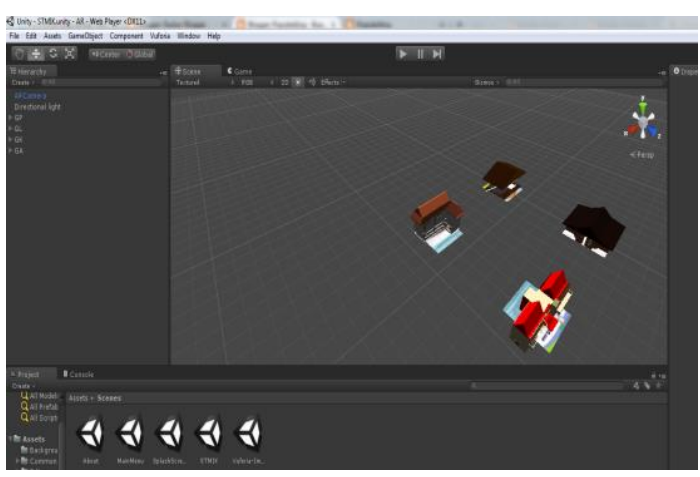

Figure 8. Display of Unity to Create Games

Users can download and install the Luluncatan and Oorayan Game applications in Playstore. The application will continue to be developed after being tested to several users so that it can find better weaknesses and advantages of the game to be developed. Users can search for the game in Playstore on devices with an Android platform. The target of the game users is early childhood. 


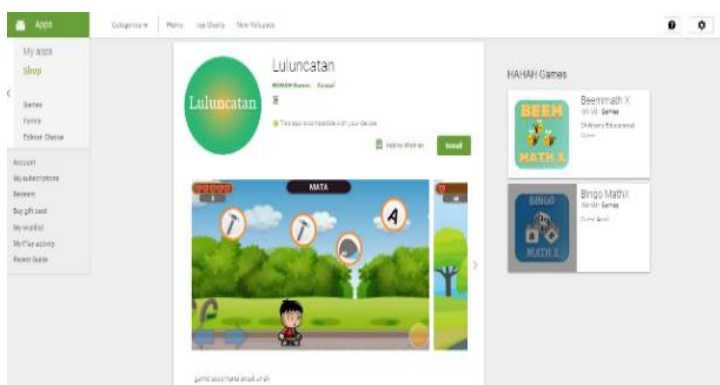

Figure 9. Luluncatan Game has Entered the Playstore

After getting an application like the picture above, users can install on a smartphone to be able to play the digital game. Both digital games have different characteristics, so users or children can play both games separately and not bore. The game is equipped with a choice of levels that can be passed if the user has completed the game at the lower level.

\section{Discussions}

Development of game media becomes an alternative in learning so that a teacher can feel the ease with the help of online-based learning media. This convenience is an attraction for students to continue learning independently and more actively. The independence of students in learning or self-directed learning becomes the main foundation of $21^{\text {st }}$-century learning, so the application of technology to learning becomes an obligation that cannot be separated between learning, students, and teachers.

Game-based learning has been applied to early childhood, especially when the game becomes the main media in classroom learning. The teachers have been trained in playing various types of games, so when they teach they don't feel stiff or worried in conveying the type of game. The game turned out to have a special attraction for students, so students feel happy and forget time.

A teacher was required to has the ability to collaborate games into learning. This ability was part of the competencies that must be mastered by a prospective teacher. Even on every education-based campus or LPTK (Institute of Teachers' Education), there are many materials or elements of the game that are learned by students, especially PGSD (Elementary School Teacher Education) and PGPAUD (Early Childhood Education Teacher Education). Although at the end of this era, a lot of learning focused on collaboration with technology.

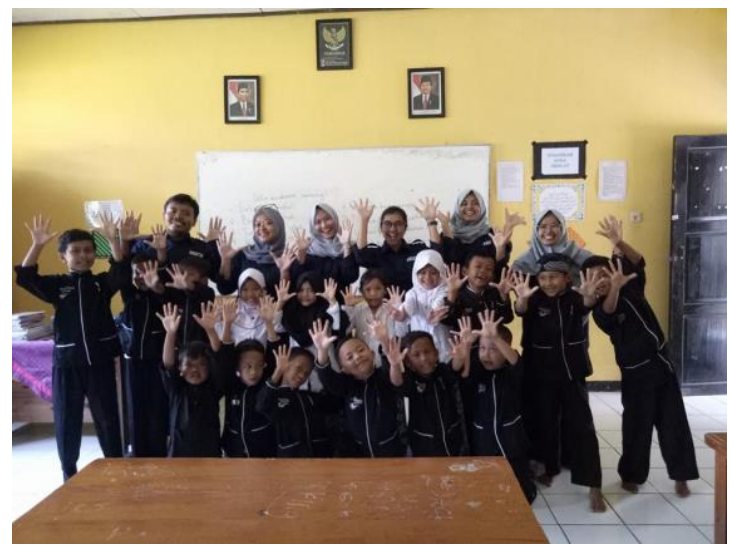

Figure 10. Teacher and student collaboration in the game

Technology-based learning was increasingly prevalent in the classroom, especially early childhood. This was influenced by the habits of children who daily collaborate more with technology or gadgets. Gadgets have an impact that can cause addiction, especially if children are accustomed to playing with gadgets, children will continue to use gadgets and the development of social interactions is hampered (Samodro, 2018). Even though the teacher must make sure the child stays socialized with other people when playing with gadgets (Astuti, 2017). Thus the role of parents and teachers is very influential on children's activities with the gadget being played.

The development of traditional digital games was a strategic step as part of parental supervision of children. In addition, they have character values inserted in games. Children will be trained in vocabulary in order to improve verbal abilities. In addition, fertilizing national values is also found in the games. This is proven by the existence of traditional games introduced to children. Given that children today are more familiar with modern games than traditional games.

The stages of developing traditional digital games were based on market needs by going through the stages of game planning first. Game planning was done using a use case activity model to describe the data flow model and system functionality when running. The modeling used in this study is the Unified Modeling Language. In addition, software and hardware requirements analysis were carried out as a supporting tool for building products. 
The next stage was game design and development, which is designing the product as an attractive user interface. This design function is expected to make users interested in visiting or playing the game continuously. Making this game design is done based on vectors and bitmaps which will later be incorporated into unity and developed into games.

The next stage was an evaluation that the testing process carried out to test whether the software produced can function or not in accordance with the stages carried out in previous phases. The result is a game that can be operated by children. Tests carried out at the black box stage which showed the test class was successful. In the portability testing section, testing was carried out on 10 different devices or gadgets to ensure that the product can be installed and can be played properly. Based on the test results from the portability aspect by using a different smartphone, it can be concluded that the traditional digital game application can run well without errors. Thus the application in the portability aspect has entered into a very good category.

The trial on the usability aspect was conducted to test the feasibility of the product by being distributed to users or users in the form of questionnaires. This questionnaire is distributed to users with criteria as media experts and material experts. There are two aspects assessed in this section, namely: material aspects and learning aspects. The results of the assessment of the two aspects can be seen from the following table:

Table 1. Material test Results

\begin{tabular}{clc}
\hline No & Assessment Aspect & Percentage \\
\hline 1 & Material Aspects & $82,91 \%$ \\
2 & Learning Aspects & $79,58 \%$ \\
\hline
\end{tabular}

Table 2. Media aspect test results

\begin{tabular}{clc}
\hline No & Assessment Aspect & Percentage \\
\hline 1 & Displays Aspects & $80 \%$ \\
2 & Navigations Aspects & $77,083 \%$ \\
3 & Game of Learning & $70,83 \%$ \\
& Aspects & $78,12 \%$ \\
4 & $\begin{array}{l}\text { Product Resilience } \\
\text { Aspects }\end{array}$ \\
5 & Additional Information & $72,91 \%$ \\
& Aspects \\
\hline
\end{tabular}

Based on the table above it can be seen that the results of the material aspects test have a percentage of feasibility: (1) material aspects of $82.91 \%$; and (2) the learning aspect was $79.58 \%$. In the aspect of the media it has a percentage of feasibility: (1) the display aspect was $80 \%$; (2) navigation aspects of $77.083 \%$; (3) learning game aspects of $70.83 \%$; (4) product durability of $78.12 \%$; and (5) additional information aspects of $72.91 \%$.

Based on the results of testing, the average usability aspect is above $70 \%$, so that both aspects of the test are considered feasible and good. Although in the aspect of the game learning the value shows $70.83 \%$ so it needs improvement. The low aspect actually lies in point 4, namely: There is a challenging competition. Actually, the concept of this game is more to improve verbal abilities, so the challenges in the game were not as great as expected.

\section{CONCLUSION}

The conclusions of this research were: (1) the results of testing from the portability aspect using a different smartphone, it can be concluded that traditional digital game applications have entered into a very good category, section testing is carried out on 10 different devices or gadgets to ensure that the product can be installed and can be played properly; and (2) the results of testing usability aspects averaged over $70 \%$, so that in both aspects the test was considered feasible and good. Although in the aspect of learning games the score shows $70.83 \%$ so it needs an increase.

Based on the test results from the portability aspect by using a different smartphone, it can be concluded that the traditional digital game application can run well without errors. Thus the application in the portability aspect has entered into a very good category. While the results of testing usability aspects averaged over $70 \%$, so that in both aspects the test was considered feasible and good. Although in the aspect of learning games the score shows $70.83 \%$ so it needs an increase. The low aspect actually lies in point 4 , namely: There is a challenging competition. Actually, the concept of this game is more to increase verbal ability, so the challenges in the game were not as great as expected. 


\section{ACKNOWLEDGMENTS}

This research was funded by Lembaga Penelitian dan Pengabdian Kepada Masyarakat (LPPM) Universitas Pendidikan Indonesia. The researchers are very grateful to all the teachers and students who have helped in completing this research article.

\section{REFERENCES}

Alanazi, T. (2017). The Efficiency of Using Educational Electronic Games in Improving English Language Skills for Fourth Elementary Grade Students. International Journal of Humanities and Social Science, 7(1).

Allsop, Y., \& Jessel, J. (2015). Teachers' Experience and Reflections on GameBased Learning in the Primary Classroom: Views from England and Italy. International Journal of GameBased Learning, 5(1), 1-17.

Astuti, L. (2017). Tips Atur Penggunaan Gadget pada Anak. Retrieved from https://www.viva.co.id/gayahidup/parenting/958777-tips-aturpenggunaan-gadget-pada-anak

Dehkordi, M. R. (2017). The Educational Impact of Traditional Games: the Role of Zurkhaneh Sport in Educating Children. International Journal of Science Culture and Sport, 5(1).

Febrian, D. (2015). Menyulap Permainan Tradisional Menjadi Digital. Retrieved from https://klasika.kompas.id/menyulappermainan-tradisional-menjadi-digital/

Firdaus, A. (2017). Kebanyakan anak Indonesia lupa permainan tradisional. Retrieved from https://www.antaranews.com/berita/6304 41/kebanyakan-anak-indonesia-lupapermainan-tradisional

Majid, N. W. A., \& Sudira, P. (2017). Proses perolehan kompetensi TIK melalui program praktik industri siswa SMKN 2 Pengasih Kulon Progo. Jurnal Pendidikan Vokasi, 7(1), 14-29.

Pressman, R. S. (2010). Software Engineering: a practitioner's approach. New York: McGraw-Hill.
Pribadi. (2010). Dampak Positif dan Negatif Komputer Bagi Anak Usia Dini. Retrieved October 10, 2017, from http://pauddikmaskalsel.kemdikbud.go.i $\mathrm{d} /$ index.php/artikel-paud-dandikmas/347-dampak-positif-dan-negatifkomputer-bagi-anak-usia-dini

Samodro, D. (2018). Dampak Negatif Gadget bagi Anak, Psikolog: Anak Malas Belajar. Retrieved from https://www.liputan6.com/health/read/32 35563/dampak-negatif-gadget-bagianak-psikolog-anak-malas-belajar

Saputra, N. E., \& Ekawati, Y. N. (2017). Tradisional Games in Improving Children's Basic Abilities. JURNAL PSIKOLOGI JAMBI, 2(2), 48-54.

Sembiring, T. (2014). Siaran Pers Tentang Riset Kominfo dan UNICEF Mengenai Perilaku Anak dan Remaja Dalam Menggunakan Internet. Retrieved July 2, 2018, from http://kominfo.go.id/index.php/content/d etail/3834/Siaran+Pers+No.+17-PIHKOMINFO-22014+tentang+Riset+Kominfo+dan+UN ICEF+Mengenai+Perilaku+Anak+dan+ Remaja+Dalam+Menggunakan+Internet +/0/siaran_pers\#.Vt-DHPI97IU

Shiratuddin, N., \& Zaibon, S. B. (2010). Mobile game-based learning with local content and appealing characters. International Journal of Mobile Learning and Organisation, 4(1). https://doi.org/https://doi.org/10.1504/IJ MLO.2010.029954

Vitianingsih, A. V. (2016). Game Edukasi Sebagai Media Pembelajaran Pendidikan Anak Usia Dini. Jurnal INFORM, 1(1), $1-8$.

Wulandari, P. (2016). Anak Asuhan Gadget. Retrieved October 9, 2018, from http://health.liputan6.com/read/2460330/ anak-asuhan-gadget

Yasmin, P. (2016). Asal Digunakan dengan Tepat, Gadget Bisa Jadi Sarana Belajar Anak. Retrieved from https://health.detik.com/fotohealth/d3357796/asal-digunakan-dengan-tepatgadget-bisa-jadi-sarana-belajar-anak 